\title{
14-Hydroxylation of Opiates: Catalytic Direct Autoxidation of Codeinone to 14- Hydroxycodeinone
}

Qibo Zhang, Joseph O. Rich, ${ }^{\dagger}$ Ian C. Cotterill, David P. Pantaleone, ${ }^{\ddagger}$ and Peter C. Michels ${ }^{\star}$ Albany Molecular Research, Inc., Bioscience Division, 21 Corporate Circle, P.O. Box 15098, Albany, NY 12212-5098

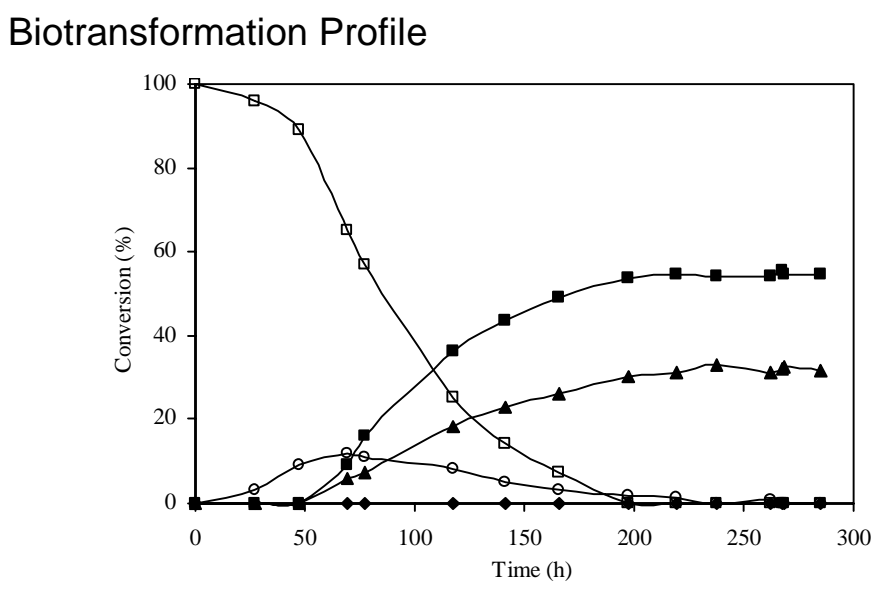

Time course of biotransformation of codeine $(0.5 \mathrm{~g} / \mathrm{L}, \square)$ to codeinone $(\bullet)$, 14-hydroxycodeinone (०), 14-hydroxycodeine (-), and 7,8dihydrocodeine ( $\mathbf{\Lambda}$ ) by M. neoaurum.

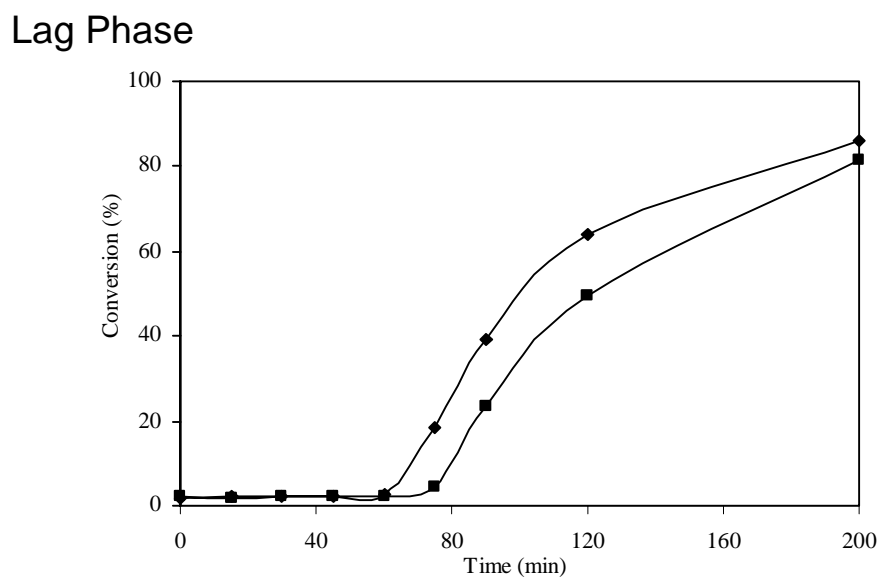

Time course of 14-hydroxylation of codeinone $(2 \mathrm{mM})$ in the presence of thiosulfate $(2.5 \mathrm{mM})$ and $\mathrm{MnSO}_{4}(7 \mu \mathrm{M}(\boldsymbol{\bullet})$ or $42 \mu \mathrm{M}(\bullet))$ in phosphate buffer (75 mM, pH 8.0). 


\section{Experimental Procedures}

\section{HPLC Analysis.}

Analytical HPLC was performed on a Shimadzu system using an Alltech Alltima C8 column $(7.0$ x $53 \mathrm{~mm}, 3 \mu)$ with a $\mathrm{CH}_{3} \mathrm{CN}$-water mobile phase containing $0.1 \%$ trifluoroacetic acid at a flow rate of $1.0 \mathrm{~mL} / \mathrm{min}$ and ambient temperature. Detection was at $284 \mathrm{~nm}$ with a runtime of $21 \mathrm{~min}$. Gradient program: $100 \%$ water at 0 minutes, linear gradient to $20 \%$ organic in 8.5 minutes, linear gradient to $50 \%$ organic at 13.5 min, linear gradient to $80 \%$ organic at $14.5 \mathrm{~min}$, hold at $80 \%$ organic until $16.5 \mathrm{~min}$, back to $100 \%$ water at $17 \mathrm{~min}$, re-equilibrate at $100 \%$ water for $4 \mathrm{~min}$. Codeinone has a retention time of $11.94 \mathrm{~min}$ and 14-hydroxycodeinone of $11.45 \mathrm{~min}$.

\section{4-Hydroxylation of Codeinone by Manganese(II) Sulfate and Sodium Thiosulfate}

To a $50 \mathrm{~mL}$ plastic centrifuge tube were added $4.8 \mathrm{~mL}$ of phosphate buffer $(75 \mathrm{mM}, \mathrm{pH} 8.0), 100 \mu \mathrm{L}$ of codeinone (100 mM in DMF, $10 \mu$ mole), $20 \mu \mathrm{L}$ of sodium thiosulfate (640 mM in water, $25 \mu$ mole), and $40 \mu \mathrm{L}$ of $\mathrm{MnSO}_{4}$ $(0.88 \mathrm{mM}$ in water, $0.035 \mu$ mole $)$. This reaction mixture was kept in a rotary shaker at $29{ }^{\circ} \mathrm{C}$ and $300 \mathrm{rpm}$ for $3 \mathrm{~h}$. A sample of this mixture $(0.5 \mathrm{~mL})$ was extracted with chloroform $(0.5 \mathrm{~mL})$, and the organic phase was separated and evaporated to dryness. The residue was dissolved in $100 \mu \mathrm{L}$ of DMF for HPLC analysis. The result indicated $\sim 85 \%$ of codeinone was converted to 14-hydroxycodeinone. The identity of the 14-hydroxycodeinone was supported by an HPLC retention time match to that from a standard sample, and confirmed by LCMS, which showed an $\mathrm{m} / \mathrm{z} 314[\mathrm{M}+\mathrm{H}]^{+}$in positive mode. The remaining reaction mixture was also extracted with chloroform, and the organic extract was evaporated to dryness. The residue showed a ${ }^{1} \mathrm{H}$ NMR spectrum match to that of a standard sample. This was also the general procedure.

\section{4-Hydroxylation of Codeinone Using Potassium Permanganate and Sodium Thiosulfate.}

To a $2 \mathrm{~L}$ glass reactor were added $500 \mathrm{~mL}$ of potassium phosphate buffer $(50 \mathrm{mM}, \mathrm{pH} 6.6)$ and codeinone $(0.5 \mathrm{~g}$, 1.7 mmole) with stirring. After the codeinone had dissolved, the $\mathrm{pH}$ of the solution was adjusted to 8.0 with $45 \%$

$\mathrm{KOH}$, and maintained automatically using $1 \mathrm{~N} \mathrm{NaOH}$ and $1 \mathrm{~N} \mathrm{HCl}$. To this solution were added $5 \mathrm{~mL}$ of sodium thiosulfate ( $1 \mathrm{M}$ in water, 5.0 mmole) and $0.3 \mathrm{~mL}$ of potassium permanganate $(95 \mathrm{mM}$ in water, $0.03 \mathrm{mmole})$. The reaction mixture was sparged with air and stirred at room temperature. After $2.5 \mathrm{~h}$ the $\mathrm{pH}$ of the solution was adjusted to 12.0 by the addition of $1 \mathrm{M} \mathrm{NaOH}$ and the product was extracted using methylene chloride $(3 \times 200$ $\mathrm{mL})$. The combined organic phase was dried $\left(\mathrm{MgSO}_{4}\right)$ and evaporated to give crude 14-hydroxycodeinone (357 $\mathrm{mg}$ ) as an off-white solid. Crystallization from chloroform/petroleum ether (40/60) gave 14-hydroxycodeinone (300 mg, $57 \%$ ) with purity greater than $99 \%$ by HPLC. ${ }^{1} \mathrm{H}$ NMR (500 MHz) spectrum in DMSO- $d_{6}$ was identical to that of a standard sample. 